\title{
Numerical studies on impact tests of a full-size metal storage cask
}

\author{
N. Kageyama \& K. Shirai \\ Civil Engineering Research Laboratory, \\ Central Research Institute of Electric Power Industry, Japan
}

\begin{abstract}
The necessity of the interim dry storage of nuclear spent fuel using metal casks has risen year by year. Metal gaskets have been used worldwide to prevent leaks from the metal cask during long-term storage. There are still uncertainties for the impact behaviours of the metal cask without impact limiters under severe impact loads, such as drop or tipping-over events in the interim storage facility. Therefore, it is very important to clarify the dynamic behaviour of the metallic gaskets subjected to sliding and opening movements of the lid structures during impact loads.

To demonstrate the structural integrity and leak-tightness of gasketed joints of the metal cask against drop impacts, many impact tests and analysis have been performed based on transport regulations or storage accident scenarios. The inert gas will be released instantaneously under very slightly opening or sliding movements of the lid structures. Until now, there has been less evaluation data concerning the instantaneous leak rates from the lid gasket during impact loading.

Therefore, two impact tests with the full-size metal cask (horizontal drop and rotational impact onto concrete floor) have been executed and the relationships between gasket movements and the leak rate of inert gas have been clarified. Moreover, according to the drop analysis using dynamic analysis code LS-DYNA and the comparison with the experimental results, the impact behaviour of the complicated gasketed joints can be simulated accurately and directly.
\end{abstract}

Keywords: interim dry storage, metal storage cask, lid gasket and LS-DYNA. 


\section{Introduction}

As the demand for electricity grows, the amount of spent fuel discharged from nuclear power plants has increased. Therefore, the need for interim dry storage has risen year by year. For interim dry storage, the metal cask with the metallic lid gasket have been used worldwide to keep high leak-tightness for long-term storage.

Generally, leak-tightness of metallic gasket joints is very sensitive to \sliding and opening movements by external impact load. However, there are still uncertainties for the impact behaviours of the metal cask without impact limiters under severe impact loads, such as drop or tipping-over events in interim storage facility. Therefore, it is very important to clarify the dynamic behaviour of the metallic gaskets subjected to sliding and opening movements of the lid structures during impact loads.

In this study, two drop tests, a horizontal drop test and a rotational impact test, were performed using full-size metal cask model [1]. In these tests, sliding and opening movements of lids are measured in detail.

The next step, in order to establish an evaluation method of the behaviour of the lid structure during impact load, post-analysis for drop tests was performed using dynamic analysis code LS-DYNA.

\section{Impact test with the full-size metal cask onto concrete floor}

In order to measuring movements of the lid structure of metal cask during the impact load, two impact tests of the full-size metal cask were performed. The metal cask without impact limiters was dropped onto the concrete floor, which simulates the floor of an interim dry storage facility.

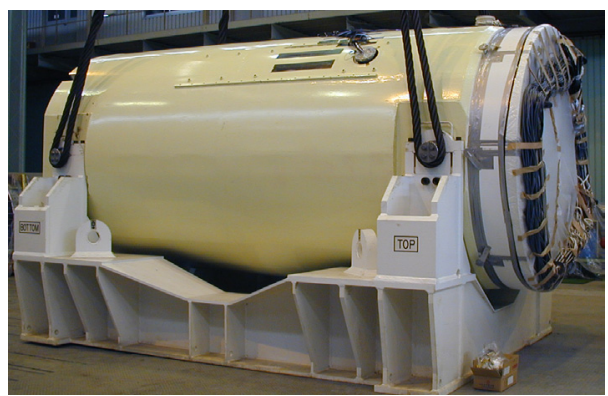

Figure 1: Overview of full-size metal cask model.

\subsection{Full-size metal cask model}

Figure 1 shows an overview of the full-size metal cask model for impact tests, and Table 1 shows the main specifications of this model. This model has been designed as metal cask for dry storage and transportation of 21 PWR-type fuel assemblies. 
This cask has a double lid structure and lid gaskets are double type metal gasket made of aluminium coating material. For primary and secondary lids, a section diameter of the gasket is $5.6 \mathrm{~mm}$ and $10 \mathrm{~mm}$, respectively.

This cask has a gap between the lid side and body. At initial conditions, primary and secondary lids are set carefully to make the gap equal. A nominal gap of primary and secondary lids at one side is $1 \mathrm{~mm}$ and $0.5 \mathrm{~mm}$, respectively.

Table 1: $\quad$ Specification of metal cask model.

\begin{tabular}{|c|c|c|c|}
\hline Part & Material & Size (mm) & $\begin{array}{l}\text { Weight } \\
\text { (ton) }\end{array}$ \\
\hline Body & $\begin{array}{c}\text { Carbon steel } \\
\text { (ASTM A350LF5) }\end{array}$ & $\begin{array}{c}\text { Internal Dir.: } 1672 \\
\text { Thickness: } 250\end{array}$ & \multirow[t]{4}{*}{84.6} \\
\hline $\begin{array}{l}\text { Neutron } \\
\text { Shielding }\end{array}$ & $\begin{array}{c}\text { Lightweight concrete } \\
\text { equivalent to resin }\end{array}$ & Thickness: 164 & \\
\hline Outer Shell & Carbon steel & $\begin{array}{l}\text { Outer Dir.: } 2524 \\
\text { Thickness: } 12\end{array}$ & \\
\hline Trunnion & $\begin{array}{c}\text { Stainless steel (SUS } \\
\text { F630) }\end{array}$ & Diameter: 190 & \\
\hline Primary Lid & $\begin{array}{c}\text { Carbon steel } \\
\text { (ASTM A350LF5) }\end{array}$ & $\begin{array}{l}\text { Outer Dir.: } 1946 \\
\text { Thickness: } 198\end{array}$ & 4.2 \\
\hline $\begin{array}{c}\text { Secondary } \\
\text { Lid }\end{array}$ & $\begin{array}{c}\text { Carbon steel } \\
\text { (ASTM A350LF5) }\end{array}$ & $\begin{array}{l}\text { Outer Dir.: } 2236 \\
\text { Thickness: } 235.5\end{array}$ & 5.5 \\
\hline $\begin{array}{c}\text { Basket and } \\
\text { Contents }\end{array}$ & Equivalent weight & & $3.5+21.2$ \\
\hline
\end{tabular}

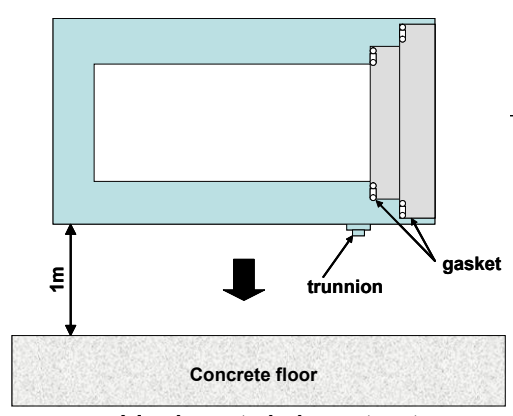

Horizontal drop test

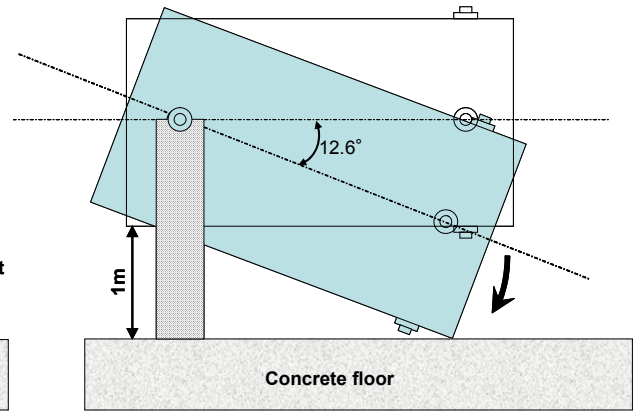

Rotational impact test

Figure 2: Impact tests condition.

\subsection{Impact test condition}

Figure 2 shows the metal cask's position in the two impact tests, horizontal drop test and rotational impact test. 
The first test is free drop from $1 \mathrm{~m}$ in a horizontal orientation. This condition simulates the drop accident during a horizontal handing at an interim dry facility. Horizontal handling operations in such facility are actually performed with impact limiters.

In the second test, considering an accident during operation of changing from horizontal position to vertical position, the direct collision with lid structure of the cask to the floor is considered by rotational impact load. The rotational center of the cask is set to the trunnion attached to the bottom sides.

\subsection{Measurement}

Table 2 shows main items of measurement for the impact tests.

The important factors in this measurement are as follows;

- To measure the instantaneous leak, the helium leak rate from lid gaskets is measured continuously during impact.

- Sliding or opening movements of the lid structure are measured precisely and continuously with inductive displacement sensors.

Table 2: $\quad$ Measurement items.

\begin{tabular}{c|c|l}
\hline Items & \multicolumn{1}{|c}{ Part } & \multicolumn{1}{|c}{ Measuring point } \\
\hline \multirow{4}{*}{ Acceleration } & Main body & Axial center $\left(0^{\circ}\right.$ and $180^{\circ}$ side $)$ \\
\cline { 2 - 3 } & Primary lid & Center \\
\cline { 2 - 3 } & Secondary lid & Center \\
\cline { 2 - 3 } & Contents & Axial center $\left(180^{\circ}\right.$ side $)$ \\
\hline \multirow{2}{*}{ Displacement } & Primary lid sliding & $\begin{array}{l}0^{\circ}, 45^{\circ}, 90^{\circ}, 135^{\circ}, 180^{\circ} \text { and } \\
270^{\circ} \text { side }\end{array}$ \\
\cline { 2 - 3 } & Primary lid opening & $0^{\circ}, 45^{\circ}, 90^{\circ}, 135^{\circ}$ and $180^{\circ}$ side \\
\cline { 2 - 3 } & Secondary lid sliding & $\begin{array}{l}0^{\circ}, 45^{\circ}, 90^{\circ}, 135^{\circ}, 180^{\circ} \text { and } \\
270^{\circ} \text { side }\end{array}$ \\
\cline { 2 - 3 } & Secondary lid opening & $0^{\circ}, 45^{\circ}, 90^{\circ}, 135^{\circ}$ and $180^{\circ}$ side \\
\hline \multirow{2}{*}{ Bolt stress } & Secondary lid bolt & $0^{\circ}, 60^{\circ}, 120^{\circ}, 180^{\circ}, 240^{\circ}$ and \\
& & $300^{\circ}$ side \\
\hline \multirow{2}{*}{ Leak rate } & Primary lid gasket & \\
\cline { 2 - 3 } & Secondary lid gasket & \\
\hline
\end{tabular}

Note: $0-180^{\circ}$ direction of the metal cask is drop direction $\left(0^{\circ}\right.$ is lower side).

\subsection{Impact test result}

Tables 3 and 4 show summary of horizontal drop and rotational impact test results.

Maximum leak rates during two impact tests were lower than $1 \times 10^{-8} \mathrm{~Pa} \mathrm{~m}^{3} / \mathrm{s}$. Therefore, it is demonstrated that the integrity of the leak-tightness of the metal cask with the gasketed joints has been verified during impact loads.

And detail movements of lid structure are described in the next chapter as a comparison of the analysis result. 
Table 3: $\quad$ Summary of horizontal drop test result.

\begin{tabular}{l|l|l}
\hline \multirow{2}{*}{ Acceleration } & Main body & Max. 50 G \\
\cline { 2 - 3 } & Primary lid & Max. 16 G \\
\hline \multirow{2}{*}{ Primary lid movement } & Sliding & Max. 0.4 mm \\
\cline { 2 - 3 } & Opening & No significant change \\
\hline \multirow{2}{*}{$\begin{array}{l}\text { Secondary } \\
\text { movement }\end{array}$} & Sliding & Max. 0.3 $\mathrm{mm}$ \\
\cline { 2 - 3 } & Opening & No significant change \\
\cline { 2 - 3 } & Axial stress of bolt & No significant change \\
\hline \multirow{2}{*}{ Maximum leak rate } & Primary lid gasket & $2.38 \times 10^{-10} \mathrm{~Pa} \mathrm{~m} / \mathrm{s}$ \\
\cline { 2 - 3 } & Secondary lid gasket & $2.85 \times 10^{-9} \mathrm{~Pa} \mathrm{~m}^{3} / \mathrm{s}$ \\
\hline
\end{tabular}

Table 4: $\quad$ Summary of rotational impact test result.

\begin{tabular}{l|l|l}
\hline \multirow{2}{*}{ Acceleration } & Main body & Max. 16 G \\
\cline { 2 - 3 } & Primary lid & Max. 48 G \\
\hline \multirow{2}{*}{ Primary lid movement } & Sliding & Max. 0.6 mm \\
\cline { 2 - 3 } $\begin{array}{l}\text { Secondary } \\
\text { movement }\end{array}$ & Opening & Max. 0.11 mm \\
\cline { 2 - 3 } & Sliding & Max. 1 $\mathrm{mm} \mathrm{at} \mathrm{0} \mathrm{side}$ \\
& & Max. 0.6mm at 45 side \\
\cline { 2 - 3 } & Opening & No significant change \\
\cline { 2 - 3 } & Axial stress of bolt & $50 \mathrm{MPa}$ increase \\
\hline \multirow{2}{*}{ Maximum leak rate } & Primary lid gasket & $3.86 \times 10^{-9} \mathrm{~Pa} \mathrm{~m} / \mathrm{s}$ \\
\cline { 2 - 3 } & Secondary lid gasket & $8.37 \times 10^{-9} \mathrm{~Pa} \mathrm{~m}^{3} / \mathrm{s}$ \\
\hline
\end{tabular}

\section{Analysis of the impact test}

To confirm the accuracy of the numerical analysis of the lid structure behaviour during impact load, the analysis of the impact tests have been executed with dynamic analysis code LS-DYNA.

\subsection{Analysis model}

The analysis code is LS-DYNA Ver.970 with user subroutine of material model for concrete originally developed by CRIEPI [2].

Figure 5 shows analysis model of horizontal drop test. This model is made as a $1 / 2$ symmetric model considering the cask structure and the drop orientation. Table 5 shows a number of elements and nodes of this model.

\subsubsection{Material properties}

In this analysis model, metallic materials are used for body, lid, lid bolts, outer shell, trunnion, contents and the reinforcement bars in the concrete floor. These materials are simulated as isotopic elastic plastic material. Table 6 shows material properties applied to the calculation. 


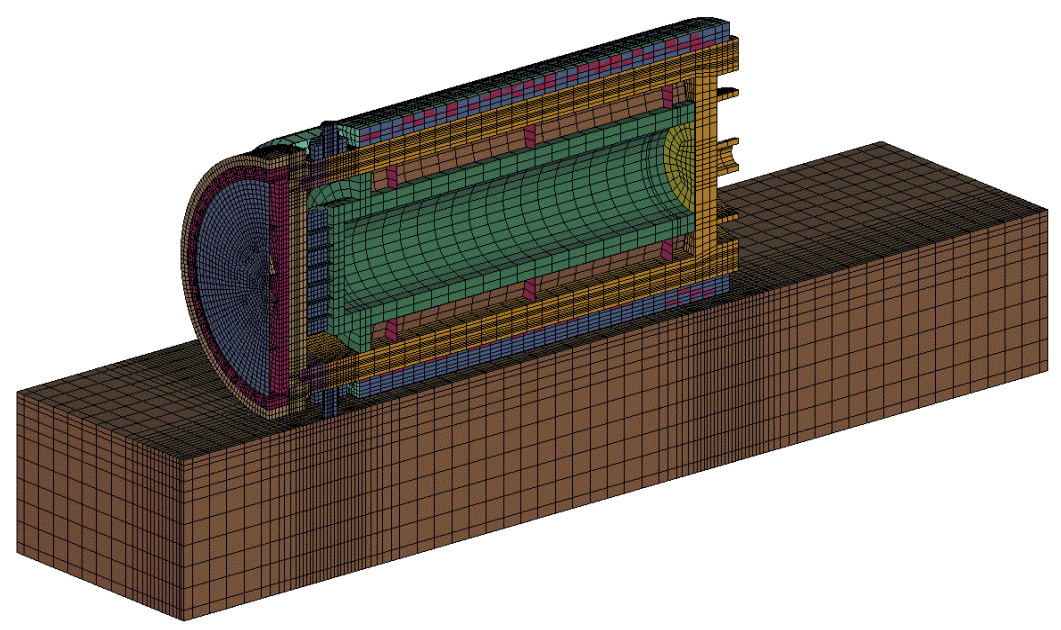

Figure 3: Analysis model of horizontal drop test.

Table 5: $\quad$ Outline of analysis model.

\begin{tabular}{c|c|c}
\hline Part & Elements & Nodes \\
\hline Main body & 91210 & 80221 \\
\hline Primary and secondary lid & 22146 & 15164 \\
\hline Contents & 3776 & 3104 \\
\hline Concrete floor & 28800 & 29658 \\
\hline Total & 145932 & 128147 \\
\hline
\end{tabular}

Table 6: $\quad$ Material properties of metallic materials.

\begin{tabular}{c|c|c|c|c|c|c|c}
\hline Part & \multirow{2}{*}{$\begin{array}{c}\text { Density } \\
\left(\mathrm{kg} / \mathrm{m}^{3}\right)\end{array}$} & $\begin{array}{c}\text { Young's } \\
\text { modulus } \\
(\mathrm{MPa})\end{array}$ & $\begin{array}{c}\text { Poison's } \\
\text { ratio }\end{array}$ & $\begin{array}{c}\text { Yield } \\
\text { stress } \\
(\mathrm{MPa})\end{array}$ & $\begin{array}{c}\text { Hardening } \\
\text { modulus }\end{array}$ & \multicolumn{2}{|c|}{$\begin{array}{c}\text { Strain rate } \\
\text { parameter }\end{array}$} \\
\cline { 7 - 9 } & & & & $\mathrm{P}$ & $\mathrm{C}$ \\
\hline Body and lid & $7.85 \times 10^{3}$ & 203460 & 0.3 & 205 & 2034 & 200 & 5 \\
\hline Lid bolts & $7.85 \times 10^{3}$ & 202000 & 0.3 & 890 & 2020 & 200 & 5 \\
\hline Outer shell & $7.86 \times 10^{3}$ & 203000 & 0.285 & 215 & 2030 & & \\
\hline Trunnion & $7.86 \times 10^{3}$ & 195000 & 0.3 & 725 & 1950 & 200 & 5 \\
\hline Contents & $7.86 \times 10^{3}$ & 203000 & 0.3 & 215 & 2030 & & \\
\hline $\begin{array}{c}\text { Reinforced } \\
\text { bar }\end{array}$ & $7.86 \times 10^{3}$ & 206000 & 0.3 & 295 & 2060 & & \\
\hline
\end{tabular}

*Note: Yield stress coefficient at strain rate $\dot{\varepsilon}=1+\left(\frac{\dot{\varepsilon}}{C}\right)^{1 / P}$.

In this analysis model, concrete materials are used for the concrete floor and lightweight concrete filled between main body and outer shell. Table 7 shows the material properties of these concrete materials. These properties have been 
determined from the results of material tests. Test Samples are prepared from the actual test model's concrete by a core boring method. These values are used for input data of user subroutine of concrete material.

Table 7: $\quad$ Material properties of concrete.

\begin{tabular}{c|c|c|c|c|c}
\hline Part & $\begin{array}{c}\text { Density } \\
\left(\mathrm{kg} / \mathrm{m}^{3}\right)\end{array}$ & $\begin{array}{c}\text { Shear } \\
\text { modulus } \\
(\mathrm{MPa})\end{array}$ & $\begin{array}{c}\text { Bulk } \\
\text { modulus } \\
(\mathrm{MPa})\end{array}$ & $\begin{array}{c}\text { Compressive } \\
\text { strength } \\
(\mathrm{MPa})\end{array}$ & $\begin{array}{c}\text { Tensile } \\
\text { strength } \\
(\mathrm{MPa})\end{array}$ \\
\hline $\begin{array}{c}\text { Concrete floor for } \\
\text { horizontal drop }\end{array}$ & $2.286 \times 10^{3}$ & 11939 & 16177 & 36.92 & 3.30 \\
\hline $\begin{array}{c}\text { Concrete floor for } \\
\text { rotational impact }\end{array}$ & $2.281 \times 10^{3}$ & 11919 & 15706 & 35.93 & 2.39 \\
\hline $\begin{array}{c}\text { Lightweight } \\
\text { concrete }\end{array}$ & $1.543 \times 10^{3}$ & 5876 & 8805 & 22.68 & 3.30 \\
\hline
\end{tabular}

\subsection{Analytical condition}

\subsubsection{Contact condition}

On every contact surface between parts of this analysis model, a slide surface condition with voids is applied. A friction coefficient of the slide surface is set to 0.14 . However, only for the flange surface of primary and secondary lid, this coefficient is set to an experimental value (0.6) obtained from the sliding test result with a scaled lid model.

\subsubsection{Tightening of lid bolts}

Initial tightening of the lid bolt is set by the method of relaxation of initial penetration. This initial tightening stress of lid bolts is equivalent to tightening torque of $2400 \mathrm{~N}-\mathrm{m}$.

\subsubsection{Initial lid position}

In the rotational impact test, it is clear from the analysis of the test result that the initial position of the secondary lid has been shifted from the center by $0.2 \mathrm{~mm}$ on the 180-degree side (opposite side of drop). Therefore, the secondary lid model for rotational impact test is set to such an eccentric position.

\subsubsection{Initial condition}

These analyses have been executed to verify the accuracy of the calculation model with our original concrete model. Initial condition of two impact tests is shown in Figure 2.

For the horizontal drop test, initial velocity $4430 \mathrm{~m} / \mathrm{s}$ equivalent to the free drop velocity from a height of $1 \mathrm{~m}$ is set to the cask model.

For the rotational impact test, initial rotational velocity is $1.09 \mathrm{rad} / \mathrm{s}$ equivalent to the velocity from the rotation of falling $1 \mathrm{~m}$. The rotational center is set to a center axis of bottom side trunnions. 


\subsection{Comparison with the test result}

Comparison between analysis and test result is summarized as follows especially taking care of lid movements. Maximum values of lid movements of analysis and test results are shown in Table 8 .

\subsubsection{Horizontal drop analysis}

Figure 4 shows the time history of the primary lid's acceleration in the drop direction. The maximum acceleration value is calculated from the slope of velocity near peak of acceleration. They are almost the same for the test result and analytical result.

Figure 5 shows the time history of the primary lid sliding. The maximum amount of sliding is same from the test result and analysis, because the friction coefficient is based on examination. However, the initial slope of sliding is not same. It is expected that it is necessary to clarify the detail of initial dynamic friction coefficient.

\subsubsection{Rotational impact analysis}

Figure 6 shows the time history of the primary lid's acceleration in the drop direction. It is found that the acceleration values calculated from the slope of velocity are more conservative than those from the drop test condition.

Figure 7 shows the time history of the secondary lid sliding. As to the lid movements, it seems that there is a good agreement between test values and calculation results by applying the experimentally obtained friction coefficient value and initial lid position. However, as shown in Table 8, the accuracy of very small opening of lids is not as good as the accuracy of the lid slide.

Table 8: $\quad$ Summary of comparison with test result.

\begin{tabular}{c|c|c|c|c|c}
\hline \multicolumn{2}{c|}{ Items } & \multicolumn{2}{c|}{ Horizontal drop test } & \multicolumn{2}{c}{ Rotational impact test } \\
\cline { 3 - 6 } \multicolumn{2}{c|}{} & Test & Analysis & Test & Analysis \\
\hline Acceleration & Primary & Max. 16G & Max. 17G & Max. 48G & Max. 40G \\
& lid & & & & \\
\hline \multirow{2}{*}{ Primary lid } & Sliding & $0.4 \mathrm{~mm}$ & $0.4 \mathrm{~mm}$ & $0.6 \mathrm{~mm}$ & $0.7 \mathrm{~mm}$ \\
\cline { 2 - 6 } & Opening & --- & --- & $0.11 \mathrm{~mm}$ & $0.01 \mathrm{~mm}$ \\
\hline \multirow{2}{*}{$\begin{array}{c}\text { Secondary } \\
\text { lid }\end{array}$} & Sliding & $0.3 \mathrm{~mm}$ & $0.2 \mathrm{~mm}$ & $0.6 \mathrm{~mm}$ & $0.4 \mathrm{~mm}$ \\
\cline { 2 - 6 } & Opening & --- & $0.02 \mathrm{~mm}$ & $0.01 \mathrm{~mm}$ & $0.05 \mathrm{~mm}$ \\
\hline
\end{tabular}

--- : No significant change.
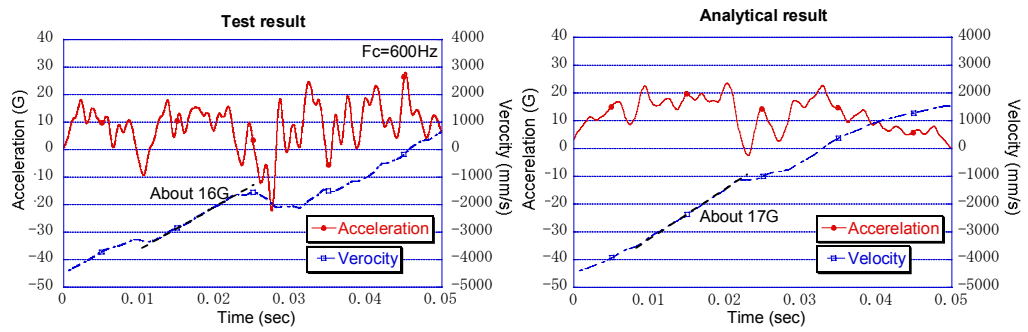

Figure 4: Time history of primary lid's acceleration. 

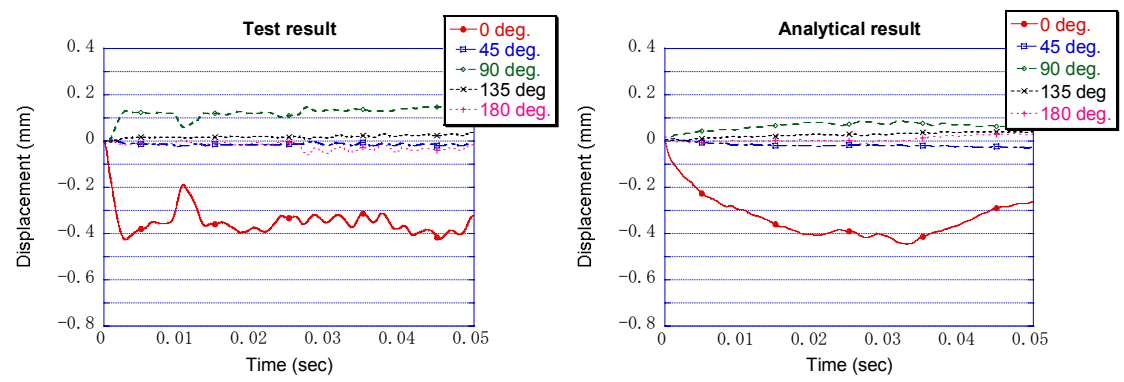

Figure 5: $\quad$ Time history of primary lid's slide.
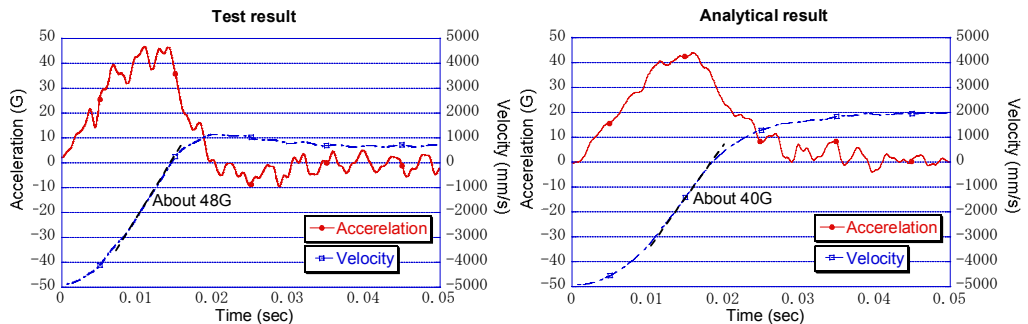

Figure 6: Time history of primary lid's acceleration.
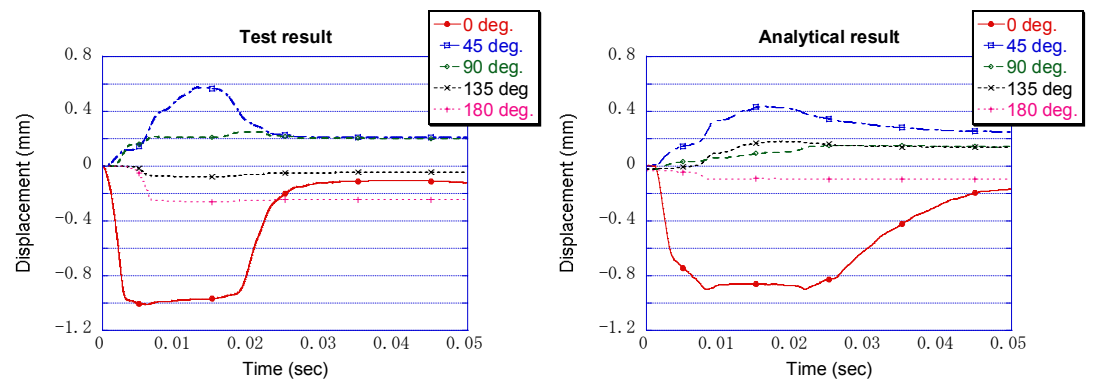

Figure 7: $\quad$ Time history of secondary lid's slide.

\section{Conclusion}

Two drop tests, a horizontal drop test and a rotational impact test, were performed using full-size metal cask model. During these drop tests, primary and secondary lid movement were observed in detail, and maximum leak rates from lid were lower than $1 \times 10^{-8} \mathrm{~Pa} \mathrm{~m}^{3} / \mathrm{s}$.

Post-analyses for drop tests were performed, and with regards to the lid movement there was a good agreement between test values and calculated results by taking care of the friction coefficient and the initial position of lid. 
410 Structures Under Shock and Impact IX

\section{Acknowledgment}

This work has been carried out under the contract from Ministry of Economy, Trade and Industry.

\section{References}

[1] H. Takeda, et al, Leakage Evaluation of Metal Cask during Drop Test, Proc. of the GLOBAL 2005, Tsukuba Japan, 2005.

[2] K. Shirai, et al., Impact Analysis of Reinforced Concrete Structure by Finite Element Method, Abiko Research Laboratory Rep. No. U93053, CRIEPI, Japan, 1993. 